\title{
0 artificial imitando 0 animal: a ideia de simulacro no vestuário de vegetarianos veganos
}

Artificial imitates nature: the idea of simulacrum in vegan's clothing

ARAUJO, Gabriella da Silva Ribeiro e I Especialista em

Gestão Estratégica do Design de Moda

Universidade de São Paulo - EACH-USP I gabriellaaraujo@usp.br

NASCIMENTO, Luís Cláudio Portugal do I Doutor em Educação de Artes

Universidade de São Paulo - FAU-USP I claudioportugal@usp.br

\begin{abstract}
Resumo
No que concerne ao vestuário utilizável pelo público vegano, há diversas alternativas sintéticas aos materiais de origem animal que os substituem em suas funções práticas, estéticas e/ou simbólicas. O presente estudo trata de uma investigação bibliográfica exploratória preliminar acerca da reflexão sobre a problemática de possíveis implicações conceituais e práticas mais notáveis, sob os enfoques práticos, estéticos, filosóficos, sociológicos e éticos, da ideia de simulacro, emulação e cópia de materiais de origem animal, em materiais artificiais, no vestuário de veganos, afim de iluminar os campos do design de moda, do veganismo e, consequentemente, dos direitos dos animais.
\end{abstract}

Palavras-chave: Veganismo. Moda ética. Design de moda. Vestuário vegano. Simulacro.

\section{Abstract}

Regarding apparel targeted at the vegan audience, there are various synthetic alternatives to materials of animal origin that fulfill the practical, aesthetic and/or symbolic function. This study is a preliminary, exploratory, bibliographical investigation about some of the most notable conceptual and practical issues on the topic - from the practical, aesthetic, philosophical, sociological and ethical viewpoints an on the idea of imitation, emulation and copying of materials of animal origin in vegans' clothing, in order to provide clarification to the fields of fashion design, veganism and, consequently, animal rights.

Keywords: Veganism. Ethical fashion. Fashion design. Vegan clothing. Simulacrum. 


\section{INTRODUC̣ÃO}

Vasta é a gama de roupas e acessórios que derivam da morte ou exploração de diversas espécies de animais. Sejam subprodutos de indústrias de maior demanda, como a pecuária e as colas utilizadas na produção de calçados, feitas a partir de restos de ligamentos de bovinos, ou oriundas de seres criados exclusivamente para a finalidade de ornamentação, tais como raposas e elefantes, abatidos exclusivamente para a extração da pele e marfim de suas presas, respectivamente, diversos animais dão origem a materiais comumente empregados na indústria têxtil e de vestuário.

Muito além da demanda por substitutos mais compatíveis aos interesses dos animais não-humanos, materiais artificiais isentos de componentes originários de animais, alternativos às peles, ossos, pelos e secreções como a seda, por exemplo, foram desenvolvidos em virtude de sua maior viabilidade econômica e de produção em escalas industriais. Em se tratando de consumo de vestuário para o público vegano, isto é, consumidores que, por motivos éticos e ideológicos, abstêm-se do consumo de produtos e serviços derivados da morte ou utilização direta de animais, materiais sintéticos e peças de vestuário que não contêm materiais de origem animal, mas que simulam suas características funcionais, estéticas e/ou simbólicas, podem servir como substitutos.

No entanto, ainda que não contenham parcelas do que, no julgamento de veganos, caracterizaria sofrimento animal, haveria implicações conceituais e práticas, em termos estéticos, semânticos, sociológicos e éticos da ideia de simulacro, emulação e cópia de materiais de origem animal aplicados a materiais sintéticos no vestuário utilizável por este público? Roupas e acessórios com tais tipos de matérias-primas englobam desde peles, pérolas e botões de ossos sintéticos, até materiais têxteis que evocam aspectos exteriores de corpos de animais, tal como o vulgarmente chamado couro sintético, estampado com padrões gráficos que aludem à textura da pele de cobra.

Considerando potencial ocorrência de indiscernibilidade da origem desta categoria de materiais, seria a utilização de alguns tipos de simulacros, sobretudo de vestuário, responsável por significante promoção da utilização produtos derivados de animais, contribuindo, assim, para a perpetuação do status quo cujos materiais de origem animal são considerados por muitos indivíduos não-veganos como aceitáveis, contradizendo aspectos da própria ideologia dos mesmos? Ou, mais importante do que este dilema filosófico e ético, em termos práticos, seriam tais substitutos fundamentais para a adequação a um novo estilo de vida daqueles que, ao aderirem à ideologia do veganismo, optaram por, entre outras coisas, boicotar o consumo de vestuário que contenha materiais provenientes de animais?

Diante de tal paradoxo e de tantos outros aspectos que permeiam esta problemática, por meio desta pesquisa bibliográfica preliminar de cunho 
exploratório, a presente investigação crítica propõe e suscita reflexões acerca da dialética entre o sintético artificial e as implicações associadas ao que alude àquilo que advém de animais, não apenas em produtos de vestuário utilizável por veganos, como também por meio de estudos de casos que extrapolam o âmbito da moda, abarcando, inclusive, exemplos identificados em alimentos veganos ou não.

Como escopo, esta pesquisa propõe iluminar não apenas o campo do design de moda, como também o do veganismo e, consequentemente, dos direitos animais, por meio da discussão e difusão de informações relevantes sobre peculiaridades que permeiam o consumo de vestuário para o público vegano, aprimorando as práticas profissionais de estilistas e designers de moda, além de expandir as fronteiras do que atualmente é depreendido do conceito de simulacro.

\section{VEGETARIANISMO E VEGANISMO: CARACTERIZAC̣õES E ACEPC̣ÕES}

De acordo com a Sociedade Vegetariana Brasileira (2013), são considerados vegetarianos indivíduos cujo regime alimentar exclui todos os tipos de carnes. Semelhante acepção é dada pela International Vegetarian Union (2013), que considera vegetarianismo como a dieta derivada de plantas, sem carne e com ou sem laticínios, ovos e/ou mel.

Já o termo 'veganismo', compreende uma filosofia de vida baseada em valores éticos e nos direitos dos animais. Consiste na abstenção da contribuição direta e voluntária com qualquer forma de exploração, uso, abuso e assassinato de animais. Todo vegano é, em detrimento de seus princípios éticos, vegetariano. Porém, nem todo vegetariano é, necessariamente, vegano: a distinção é de natureza ideológica e se manifesta em seu modo de vida. Por todos esses aspectos, veganos, além de adeptos da dieta vegetariana estrita, abolem o consumo de produtos que contêm ingredientes e materiais derivados de animais vivos ou mortos (tais como: cosméticos, produtos de limpeza, de vestuário, mobiliário, entre outros), bem como a utilização de animais para fins de trabalho escravo, rituais religiosos, esportivos, de entretenimento e de experimentação científica (GUIMARÃES, 2010).

Ao longo do tempo, o homem desenvolveu e aprimorou técnicas para deter os animais junto a si e usá-los para fins de força de tração, extração de suas carnes, peles, lã, leite, ovos e outras secreções, diversão e medicamentos. O uso de animais não-humanos para fins de interesses, negócios e necessidades é tão amplamente disseminado em diversos âmbitos da produção e do consumo de mercadorias e serviços (FELIPE, 2010) que, em termos práticos, ser totalmente vegano tornou-se algo virtualmente impossível (MÜLLER, 2010). 
Quando julgamos ter alcançado um patamar razoável de abolição de produtos de origem animal que antes compunham a cesta básica de nossa aquisição diária, somos confrontados com o fato de que quase todos os produtos da indústria química usados para confeccionar alimentos processados, tecidos, calçados sintéticos e outros itens do uso diário contém ingredientes produzidos com componentes derivados ou extraídos de animais (FELIPE, 2010).

Diante deste constante desafio, veganos são consumidores que, na medida do possível, averiguam minuciosamente a possível eviedência de violação de direitos de animais, não somente nas entrelinhas da lista de ingredientes ou materiais intrínsecos de cada produto ou serviço consumido, como também por meio da investigação de possíveis traços imateriais da utilização de animais. Para os veganos, o eventual consumo de produtos resultantes de uma realidade não aprovada, além de moralmente incômodo, caracterizaria conivência com e o financiamento de tais práticas.

Além disso, segundo o argumento de Ferrigno (2012, p. 72), a abstenção do consumo de derivados de animais poderia impactar sua produção, uma vez que repercutiria em menor demanda pelos mesmos.

\section{VESTIR DE UM VEGANO}

No que tange artigos de vestuário, esta realidade não é muito diferente. Tal como suas preferências alimentares, em coerência com sua filosofia de vida, veganos, na medida do possível, não se vestem com nada que contenha parcelas de corpos ou secreções de animais. Em consonância com tal premissa, para a filósofa vegana, especialista em bioética, Sônia Felipe (2010), "a pele e a preservação da intimidade do corpo humano não devem ser protegidas à custa da tortura e morte de quaisquer animais".

Sejam facilmente identificáveis ou imperceptíveis, peles, penas, pelos, pérolas, conchas, ossos e secreções de diversos animais compõem ou ornamentam diversos produtos para o vestuário humano. No Brasil, embora haja marcas de produtos de vestuário especificamente voltadas para o público vegano, de acordo com Marly Winckler, então presidente da Sociedade Vegetariana Brasileira, ainda seriam insipientes para atender à demanda (FERREIRA, 2013). Mesmo que não sejam declaradamente veganas, há também marcas comuns que produzem, não necessariamente com ideais éticos, parte ou a totalidade de suas roupas, calçados e/ou acessórios sem ingredientes de origem animal, a partir de materiais vegetais, minerais ou sintéticos, que muito se assemelham em sua aparência e funções aos materiais de origem animal, como é o caso dos couros sintéticos amplamente utilizados em calçados, bolsas, carteiras, cintos, etc. 


\title{
4 ACEPC̣ÕES E IMPLICAC̣ÕES DE ALGUNS EXEMPLOS DO EVENTO DO SIMULACRO DENTRE E ALÉM DAS BALIZAS DO VEGANISMO
}

Segundo o dicionário Michaelis (2009) da língua Portuguesa, simulacro é um vocábulo utilizado para designar o que é criado pela fantasia, que representa algo, sem realidade. Para Pompeu (2013), significa imitação, parecença, semelhança e/ou representação. Com um tom mais crítico nas definições, de acordo dicionário Houaiss (2007), o termo também caracteriza cópia grosseira, malfeita, arremedo.

Em contrapartida à definição do último dicionário citado, para Gilles Deleuze (1974, p. 267-8), filósofo francês que analisou o conceito de acordo com as ideias de Platão, o simulacro não se trataria de uma cópia degradada, pois abarcaria uma potência que nega tanto o original como a cópia, tanto o modelo como sua reprodução. Em si, o simulacro é distinto, singular, mas, para um espectador alheio, é somente uma impressão (SALLES, 2004).

\begin{abstract}
O simulacro implica grandes dimensões, profundidades e distâncias que o observador não pode dominar. É porque não as domina que ele experimenta uma impressão de semelhança. O simulacro inclui em si o ponto de vista diferencial; o observador faz parte do próprio simulacro, que se transforma e se deforma com seu ponto de vista (DELEUZE, 1974, p. 264).
\end{abstract}

Jean Baudrillard (1992), sociólogo, também francês, reconhecido por discorrer filosófica e mais profundamente sobre o conceito de simulacro em sua obra "Simulacros e simulações", defende a ideia de que, na contemporaneidade, vivemos em uma era cujos símbolos têm mais valia e influência do que a própria realidade. Neste contexto, os simulacros seriam simulações imperfeitas do real que, paradoxalmente, podem ser mais atraentes ao expectador do que o próprio objeto replicado.

\begin{abstract}
A simulação já não é a simulação de um território, de um ser referencial, de uma substância. É a geração pelos modelos de um real sem origem nem realidade: hiper-real. O território já não precede o mapa, nem lhe sobrevive. É agora o mapa que precede o Território - precessão dos simulacros - é ele que engendra o Território cujos fragmentos apodrecem lentamente sobre a extensão do mapa. É o real, e não o mapa, cujos vestígios subsistem aqui e ali, nos desertos que já não são os do Império, mas o nosso. O deserto do próprio real (BAUDRILLARD, 1992, p. 7-8).
\end{abstract}

Ainda segundo o autor, o simulacro é um procedimento associado à produção de sentidos. É como uma mutação de coisas em algo semelhante 
com sua forma original. Quanto mais próximas da realidade, do objeto, menos deixam de ser uma representação. Nesse contexto, o distanciamento do original colabora para o surgimento das manifestações de simulacros. Quanto mais longe, alienado, mais se tem uma ideia do real, mais se conjectura o que é o real e menos se tem clareza do que é a realidade.

Baudrillard defende que a imagem possui quatro fases sucessivas: a primeira diz respeito à imagem como reflexo de uma realidade profunda, com boa aparência; na segunda a imagem mascara e deforma a realidade, trata-se de uma má aparência; na terceira mascara a ausência de realidade, ou seja, finge ser aparência e a quarta fase, quando a imagem não tem relação com nenhum aspecto da realidade, sendo ela o seu próprio simulacro. Em todas as fases a imagem é modificada de acordo com a realidade a fim de aparentar semelhanças que nos permita identificá-la, a partir da associação de determinadas características, com outras imagens, aparências (ALVES; CALEIRO, 2011, p. 7).

Para Alves e Caleiro (2011, p. 5), o simulacro não é algo além da realidade, tampouco constitui outra realidade. Todavia, faz parte do real e é fundamentado nele que se constitui simulacro. É uma distorção, distinção, pela qual não se pode distinguir real e imagem. É, pois, a diligência de se fazer uma imagem ser real de tal maneira que nem os modelos, sequer os clichês, interfiram em sua receptibilidade. Em síntese, trata-se de, violar um esquema de percepção.

No campo do veganismo, além dos exemplos encontrados no vestuário, que possuem materiais ou aspectos exteriores que simulam ou referenciam animais ou partes de seus corpos, a questão dos simulacros na alimentação, por exemplo, é pauta de discussão entre indivíduos deste público.

Versões veganas, ou seja, que não contêm ingredientes de origem animal, de alimentos como: linguiças, salsichas, presuntos, hambúrgueres, bifes, pizzas, brigadeiros, bolos, sorvetes, queijos e leites, imitam, em diferentes graus de fidedignidade, a aparência, sabor, textura e olfato de alimentos que, em sua versão tradicional, derivada de animais, não pertenceriam à dieta vegetariana estrita (ANDA, 2016).

Se, por um lado, tal semelhança é considerada imprescindível para agradar ao paladar e, muitas vezes, satisfazer a memória afetiva ligada aos alimentos dos quais alguns veganos têm em relação aos alimentos que optaram por não consumir mais, por outro, causa repugnância e sua aceitação é questionada por parte de veganos que se opõem ao consumo de comidas que remetam à aparência e ao paladar de ingredientes provenientes de animais. 
Na opinião de Souza (2016), vegano e articulista de blogs de sua autoria sobre questões relacionadas ao veganismo, a intolerância a imitações veganas de alimentos de origem animal é uma questão desnecessária que pode atrapalhar o entendimento sobre a essência do veganismo. O articulista supracitado considera a crítica e a reprovação ao consumo destes simulacros como mera implicância, "um conjunto de ditames moral-culturais" em relação a atitudes em que, pragmaticamente, não se pode alegar a ocorrência de desvio de ética, uma vez que não implicam diretamente em prejuízos à integridade de animais. Para ele, enquanto militância, tal dialética seria contraproducente pela possibilidade de distorcer o conceito e prejudicar a disseminação da filosofia do veganismo na sociedade, criticando o uso destes simulacros como recursos paliativos de indivíduos em fase de transição de uma dieta onívora para a vegetariana e/ou vegana.

Por outro lado, em se tratando de analogias à ressonância dos simulacros de materiais de origem animal em vestuário, alguns exemplos sobre a reverberação das acepções sobre os simulacros dentro e fora do universo dos veganos, no extremo oposto da visão de Souza (2016), são também dignos de reflexão e discussão.

Ainda no que tange a alimentação, desta vez, não direcionada aos adeptos do veganismo, alguns exemplos de comidas que, mesmo não contendo ingredientes de animais, neste caso, humanos, devido à sua similitude com estes seres, foram objetos de repúdio e polêmica. É o caso do bolo em formato de bebê, representado na figura 1, abaixo, que causou espanto e indignação de internautas em redes sociais.

Figura 1 - Bolo em formato de bebê sendo fatiado

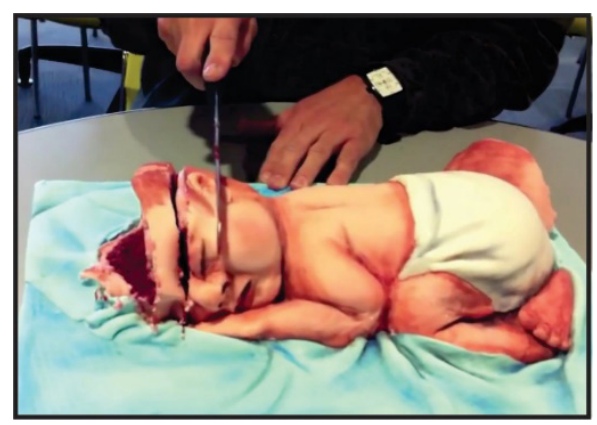

Fonte: Daily Motion (2016).

Contrariando a lógica de que a ausência de ingredientes ideológica e/ ou culturalmente não permitidos seria suficiente para tornar algo aceitável, o corte de outro bolo, desta vez em formato de aborígene, idealizado pelo artista e cozinheiro Makode Linde a fim de chamar a atenção da imprensa sobre a mutilação genital de mulheres de tribos africanas, foi interpretado como um espetáculo racista. Em performance no museu de Arte Moderna de Estocolmo, com o rosto pintado de modo que sua cabeça fosse incorporada ao bolo, 
o artista gritava de dor à medida que a obra, com massa e recheio na cor de carne humana, era fatiada na região da genitália. Após ter sido convidada e ter cortado uma das fatias, Lena Adelsohn Liljeroth, ministra da cultura da Suécia, foi duramente criticada e apontada como racista (MINISTRA..., 2012).

Figura 2 - Bolo em formato de aborígene, fatiado por ministra da Cultura sueca.

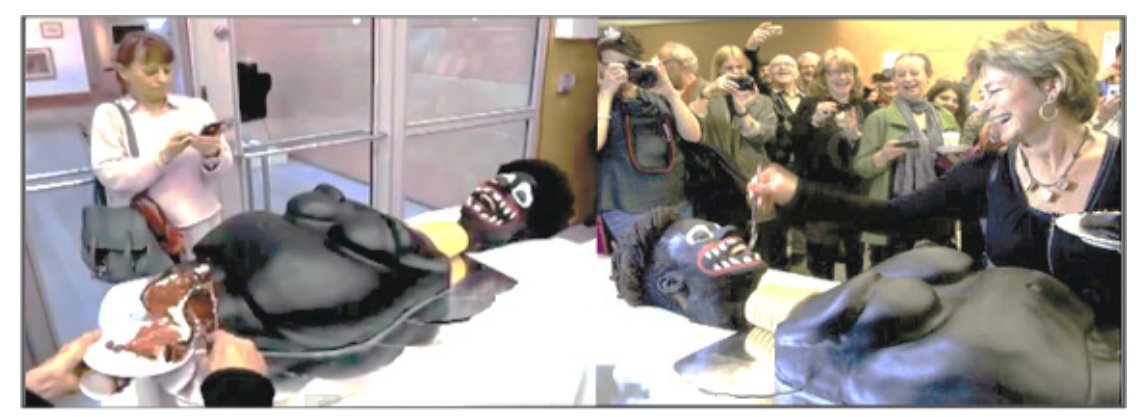

Fonte: Ministra... (2012).

Neste episódio, mesmo não se tratando de um simulacro propriamente dito, mas, sim, de um caricato arremedo da autóctone africana, idealizado para fins de protesto ao contexto supostamente opressor em que estaria inserida, foi suficiente para que $o$ ato provocasse o sentimento de aversão em algumas pessoas.

Outro exemplo do prisma semântico intrínseco dos simulacros se manifesta nas esculturas hiper-realistas do artista plástico chinês, militante dos direitos animais, Cao Hui feitas de resina e fibras, as obras foram concebidas no intuito de retratar vísceras, peles e carnes de animais cujas vidas são ceifadas para dar origem a objetos do cotidiano como mobiliário e peças de vestuário feitas com couro. Ao expor, com materiais sintéticos, aspectos intrínsecos à realidade da obtenção destes materiais, Hui provoca a reflexão para a prática de um consumo mais consciente (CONHEC,A..., 2016).

Figura 3 - Esculturas realistas em resina, de Cao Hui.

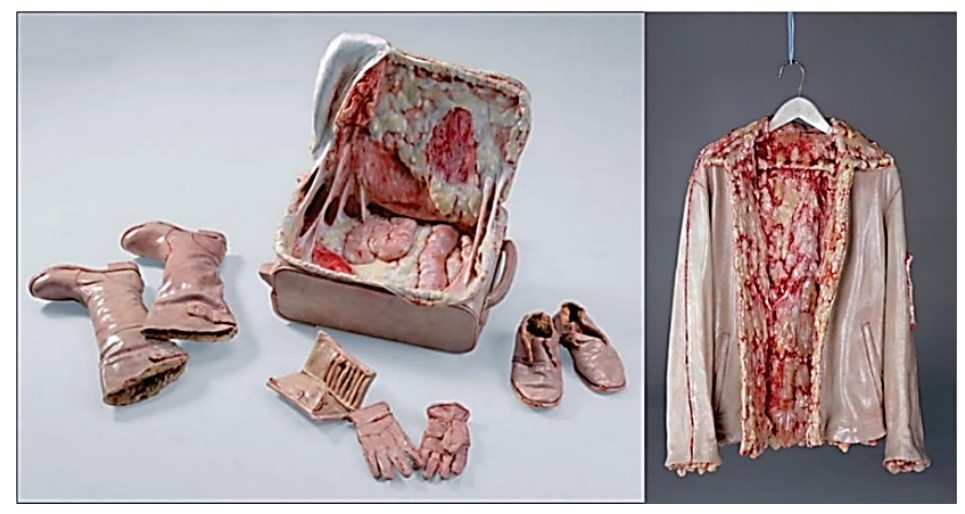

Fonte: The Indigestible... (2015). 
A parecença dos simulacros com algo moralmente inaceitável por determinado público também pode gerar repercussão digna de elucubração no campo do design de moda. É o caso do biquíni com estampa de mamilos do gênero feminino, que faz do trompe l'oéil um instrumento de protesto utilizado por uma marca estadunidense contra o que considera ser objeto de sexismo. Funcionando com um "engana-olhos", traduzido do francês para o português, é um termo utilizado para designar o recurso técnico-artístico que, por meio de ilusões de ótica e/ou truques de perspectiva, faz alusão a coisas que não existem na realidade dos materiais do objeto em questão (SABINO, 2007). Quando vista de longe, a peça em poliéster vendida pela internet da marca The Tata Top, imita a imagem do busto feminino desnudo, algo não legalmente permitido na maioria das praias e objeto de reivindicação de militantes do movimento feminista Free The Nipple (liberte o mamilo, em português) (THE TATA..., 2016).

Figura 4 - Biquíni com estampa de mamilos femininos da marca The Tata Top.

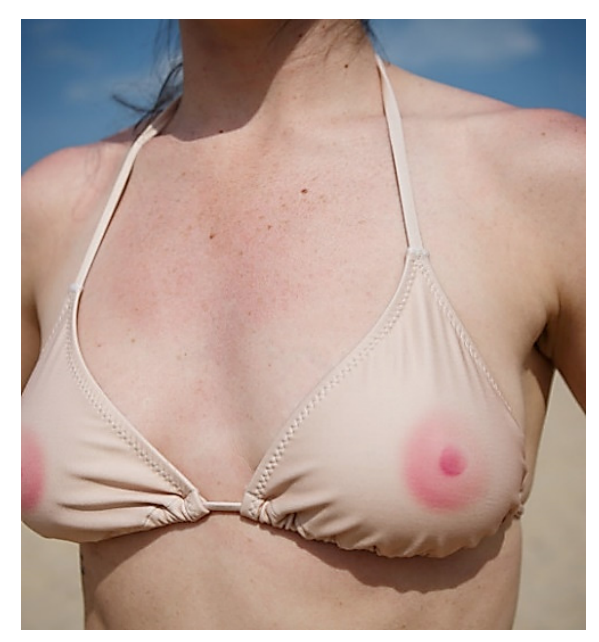

Fonte: The Tata... (2016).

Outro exemplo de materiais têxteis que provocaram a ilusão da imagem de partes do corpo feminino pode ser observado no polêmico uniforme utilizado pela seleção feminina de ciclismo colombiana, em 2014. Com uma faixa em tom de bege, semelhante à cor da pele das atletas, localizada na região da virilha até o umbigo, de acordo com a iluminação do ambiente e efeitos de luz na fotografia, o indumento utilizado aparentava simular a nudez de suas partes íntimas, o que despertou sentimentos de distintos, do deboche à reprovação. Diante do reverbério do escândalo que poderia manchar a imagem e destituir a credibilidade do time, para Carlos Pinzón, presidente da liga de ciclismo de Bogotá, em comunicado oficial, o uniforme havia sido desenhado "sem malícia" por Angie Rojas, integrante da equipe que idealizou o uniforme com o consentimento das demais companheiras. Para ele, a polêmica se deu, somente após o nono mês de treino com o traje, por conta de "um efeito visual que não se vê em outras imagens e, muito menos, no uniforme real". Ainda assim, seu 
design foi considerado por Aldo Cadena, autoridade do esporte local, como inadequado para a competição, pois, ao invés de despertar interesse sobre a equipe e seus patrocinadores, foi motivo de piada nas redes sociais da internet (CARVALHO, 2014).

Figura 5 - Uniforme da seleção colombiana de ciclismo feminino.

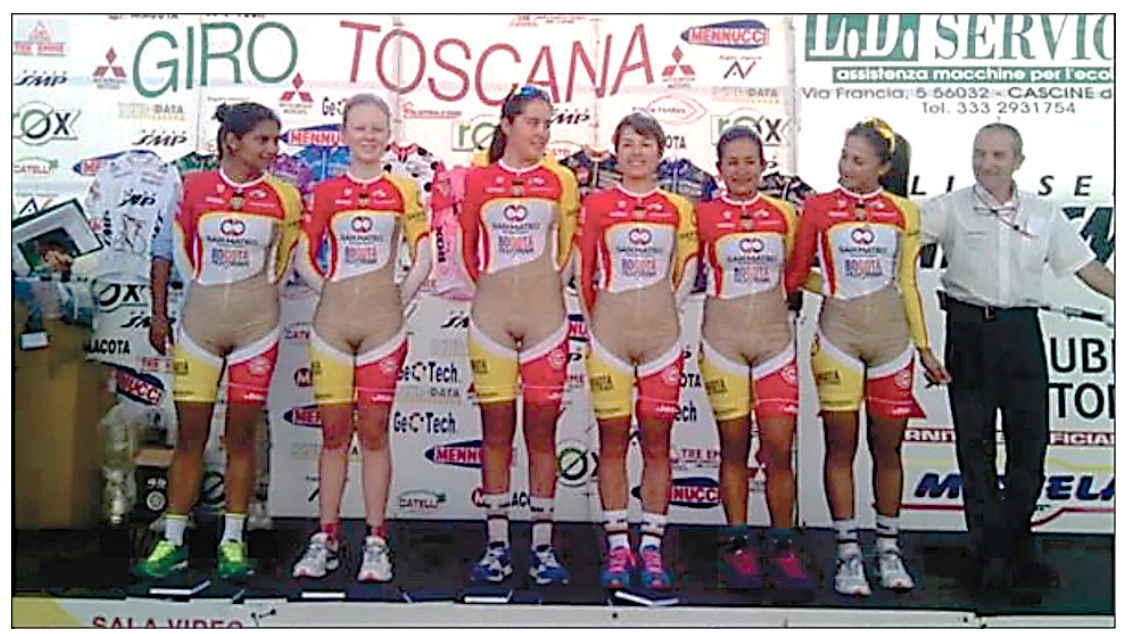

Fonte: Carvalho (2014).

Semelhante fato polêmico, ocorrido na cerimônia do Oscar de 2016, causou grande repercussão na imprensa. Enquanto se dirigia ao palco do Kodak Theatre para receber a estatueta referente à categoria de melhor figurino por seu trabalho no filme "Mad Max: estrada da fúria", a figurinista londrina Jenny Beavan causou espanto pelo que trajava fato noticiado em todo mundo, imediatamente após sua aparição (CHAVES, 2016).

"Quando uma jaqueta de couro fala mais do que um Oscar" (SHMIDT, 2016), "Vencedora de Oscar de Melhor figurino usa jaqueta de couro na cerimônia" (VENCEDORA..., 2016), "Jaqueta de couro de Jenny Beavan merece um lugar em todas as listas de melhores vestidos do Oscar" (LUBITZ, 2016) e "Vencedora do Oscar de melhor figurino foi à cerimônia com jaqueta vegana (sem couro)" (CHAVES, 2016), são alguns dos diversos títulos de matérias publicadas a respeito da roupa que vestiu na premiação.

A querela se deu ao fato de que a figurinista, ao invés de ter seguido o código de vestimenta tradicional da cerimônia, com vestido de gala, joias, penteado e maquiagem, surpreendentemente original, foi fiel a seu estilo pessoal, trajando, entre outras coisas, calça jeans, sapato fechado, e uma jaqueta de couro sintético comprada em uma loja de departamentos e customizada com cristais bordados em formato de caveira, homenageando o filme que the rendeu o prêmio (CHAVES, 2016; SCHMIDT, 2016).

Outro elemento de seu traje, discreto no tamanho, porém, notável em seu significado, foi a presença de um pequeno broche na parte frontal, com a frase "Falso, não é couro". O referido detalhe se trata de um acessório 
comercializado pela organização internacional não governamental (PETA, 2016), sigla de "Pessoas pelo tratamento ético de animais", traduzida para o português.

Embora o eco na imprensa sobre o traje da figurinista tenha ocorrido principalmente por sua autenticidade e rebeldia contra o padrão tradicional, a palavra "couro", sem especificação de sua composição, predominava nos títulos e conteúdo das manchetes. Dentre as matérias de websites supracitadas, nem todas relataram a ausência de origem animal nos materiais da jaqueta que, se feita por meio da análise das fotos de Jenny Beavan na cerimônia, só poderia ser discernida devido à presença do pequeno broche e sua mensagem. Na página da loja virtual da Peta, onde o broche é vendido, há a seguinte descrição do produto: "Não deixe outras pessoas confundirem suas roupas compassivas com roupas cruéis. Coloque nosso broche 'falso, não é couro' em sua jaqueta ou bolsa de couro falso bacana" (PETA, 2016). Implícito à existência deste acessório, estaria o indício de que haveria demanda pelos atributos semânticos presentes neste objeto, por parte de consumidores simpatizantes da utilização de vestuário isento de materiais provenientes de animais.

Figura 6 - Jaqueta de couro sintético e broche do PETA usados por Jenny Beavan.

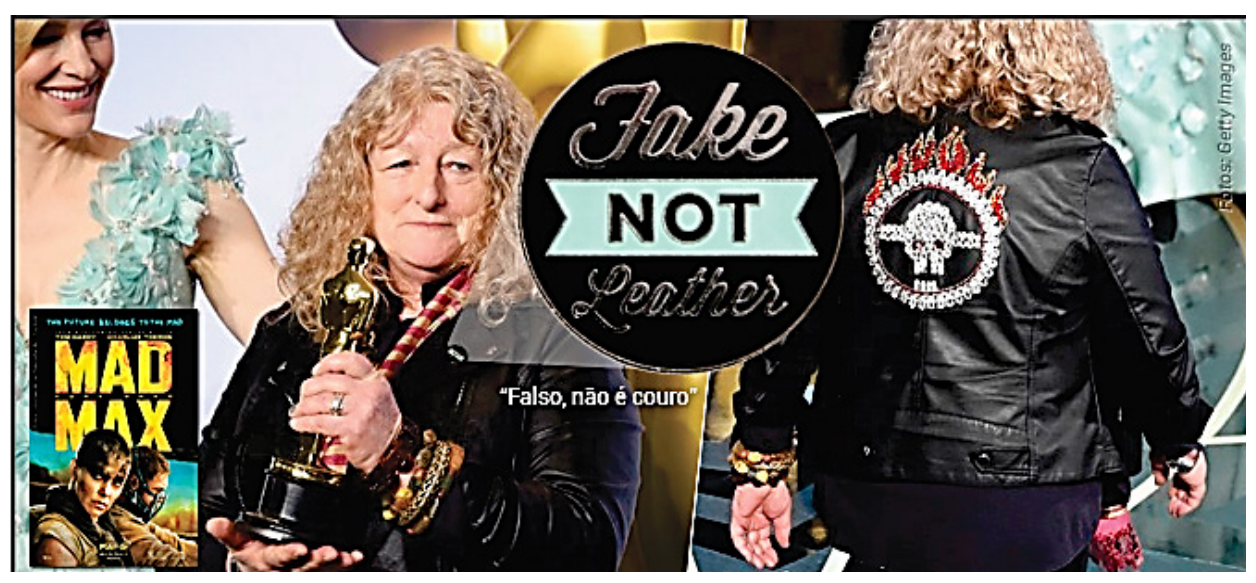

Fonte: Chaves (2016).

O mimetismo intrínseco aos simulacros de materiais de origem animal, em alguns casos, em meio à carência de discernimento sobre a distinção entre o couro sintético e o de origem animal, pode ser considerado uma questão paradoxal para os adeptos do veganismo.

Semelhante ao caso de Jenny, são as acepções equivocadas do vestuário do ator e cantor norte americano Jared Leto. Extremamente popular entre o público adulto e adolescente, o artista, que se autodeclarou vegano, é considerado uma celebridade ícone de estilo: as roupas que veste tanto nos palcos como na vida real são objeto de referência para pessoas que almejam se inspirar em sua maneira de se vestir. Em uma rápida pesquisa no site de buscas Google, as palavras-chave "Jared Leto" e "couro" resultam em dezenas de sites 
com dicas de como se é possível se inspirar e até obter peças de vestuário do singular estilo desta celebridade. No entanto, assim como no caso da figurinista supracitada, são raros os casos em que há discriminação ou ênfase na origem (sintética) da matéria prima das jaquetas, calças e acessórios vestidos pelo ator e cantor vegano. No extremo oposto da filosofia do veganismo a qual Leto incorporou ao seu estilo de vida, tais sites de dicas de como ter ou se vestir como pessoas famosas fazem ostensivas referências ao couro de origem animal, como se não houvesse diferença alguma em relação ao tipo de material que o ator utiliza.

Contrário ao uso de animais para fins que infrinjam seus direitos, em uma postagem em sua página pessoal da rede social Instagram, prefigurando possíveis alegações de contradição ideológica, fez questão de esclarecer que a calça com estampa de zebra que vestia na foto era de couro vegetal (REVISTA QUEM, 2014).

Por outro lado, nas aparições públicas em que é fotografado utilizando simulacros de materiais de origem animal, involuntariamente e indiretamente, poderia estar contribuindo para estimular o consumo de couro, seja de origem animal, vegetal ou sintética, neste caso, há milhares de quilômetros de distância, no Brasil, sem qualquer controle sobre a reverberação do que consome conscientemente, revelando a esfera paradoxal dos simulacros no campo do design de moda voltado para e utilizável por vegetarianos veganos. (JARED..., 2014).

\section{CONSIDERAC̣ÕES FINAIS}

Levando-se em consideração os desdobramentos dos casos recém discutidos, se, para alguns apreciadores do couro de origem animal, o potencial evocativo de aspectos semânticos dos simulacros apresentados neste estudo poderia ser uma não-questão, uma vez que se trataria de subproduto de uma indústria primária cujos derivados já seriam socioculturalmente aceitáveis e consumidos pelos mesmos, para indivíduos veganos, em uma análise menos superficial, poderia ser considerado um dilema ético.

Tal como um objeto de plástico ordinário em formato de revólver que, nas mãos de uma criança, pode ser visto somente como brinquedo aparentemente inofensivo - ainda que suas implicações éticas, enquanto brinquedo, já seriam questionáveis, por natureza -, em outro contexto, no escuro e em mãos de um assaltante, passaria a ter o significado da arma a que se assemelha, assim também poderia ser entendida a antinomia semântica passível de ser verificada em simulacros de materiais de origem animal em relação à filosofia do veganismo.

Como observado em casos estudados nesta investigação, muito além de materiais e produtos substitutos em funções práticas, estéticas e/ou simbólicas, feitos com ingredientes e matérias-primas alternativas aos de origem animal, a aparente similitude com uma realidade não aprovada pelos padrões ideológicos dos usuários veganos que os consomem, ao mesmo tempo em que possui evidente 
utilidade, indiretamente, também contribui para perpetuação da existência de padrões estéticos originários da percepção sobre materiais provenientes de animais, como é o caso do couro bovino e seu simulacro sintético, o courvin.

Os fatos discutidos remetem à ideia de simulacro e instigam a reflexão sobre seu papel simbólico. São indícios de que, implícita a estas imitações, há uma dimensão emblemática indissociável dos eventos, dos materiais, das formas e da visualidade. Tais evocações não apenas exercem finalidade substitutiva dos materiais originários de animais, como também manifestam implicações morais, estéticas, semânticas, etc.

Tal como os sintetizadores, instrumentos musicais eletrônicos com infinito potencial de produção de sons singulares usados, entretanto, sobretudo para reprodução com perfeição de sons já existentes, assim podem ser analisadas as implicações dos simulacros, sobretudo em termos ideais (sob a ótica do veganismo) e a longo prazo.

Ainda que a existência de imitações de materiais de origem animal seja, entre outras coisas, justificada pelo suprimento de necessidades funcionais, estéticas, afetivas e de aceitabilidade social, por outro, indiretamente, também poderia contribuir para perpetuação do consumo dos materiais com os quais se assemelham, seja por meio da imagem que carregam ou pelo simples fato de sua parecença não fomentar e reorientar a demanda por nova gama de materiais e produtos originais em sua essência, cada vez menos análogos aos materiais que supostamente acarretam dor animal.

Comovisto nesteestudo, paraalguns veganos, embora aproblematização quanto aos simulacros na alimentação não seja questão relevante, no vestuário, diante de sua utilidade no cotidiano de indivíduos que alteraram radicalmente seu estilo de vida e opções de consumo em função de motivações ideológicas, tais implicações poderiam ser mais levadas em consideração por parte de empresários do setor, estilistas e designers, na concepção de novos produtos voltados para o público sensível aos direitos dos animais.

Dado o exposto, pode-se inferir que a discussão acerca do limiar de aceitabilidade dos simulacros em suas diferentes formas de acepção é um assunto que suscita reflexão em estudos mais aprofundados, não apenas no campo da moda especificamente voltada para o público vegano, como também em estudos que investiguem o papel dos simulacros e seus desdobramentos na contemporaneidade. 


\section{REFERÊNCIAS}

ANDA. Agência de Notícias de Direitos Animais. Açougue vegano nos EUA vende imitações de carne à base de plantas. 2016. Disponível em: <http://goo. gl/88aajM>. Acesso em: 28 abr. 2016.

ALVES, Marcelle Louise Pereira; CALEIRO, Maurício de Medeiros. Simulacros e simulação: sucesso? In: CONGRESSO BRASILEIRO DE CIÊNCIAS DA

COMUNICAÇÃO, 34., 2011, Recife. Anais... Recife: INTERCOM, 2011. p. 2-7.

Disponível em: <http://goo.gl/x6puhS>. Acesso em: 5 jun 2016.

BAUDRILLARD, Jean. Simulacros e simulações. Lisboa: Relógio D’Água, 1992.

CAMARGO, Lia. Stilo: Caio Castro, Harry Styles, Jared Leto e Ryan Gosling. 2013. Disponível em: <http://goo.gl/doow5B>. Acesso em: 23 abr. 2016.

CARVALHO, André. Uniforme de equipe de ciclismo colombiana "simula" nudez e gera revolta nas redes sociais. 2014. Disponível em: <http://goo.gl/ z9Mw67>. Acesso em: 24 abr. 2016.

CHAVES, Fábio. Vencedora do Oscar de melhor figurino foi à cerimônia com jaqueta vegana (sem couro). 2016. Disponível em: <http://goo.gl/bj4rLR>. Acesso em: 27 mar. 2016.

CONHEÇA a arte perturbadora de Cao Hui. Cultura Alternativa, 30 out. 2016. Disponível em: <http://www.culturaalternativa.com.br/artes-plasticas/outros/ item/5554-conheca-a-arte-perturbadora-de-cao-hui>. Acesso em: 29 abr. 2016.

DELEUZE, Gilles. Platão e o simulacro. In: Lógica do sentido. São Paulo: Perspectiva, 1974.

DR VIRAL. Você comeria um bolo em forma de bebê? Disponível em: <http:// goo.gl/j2jq9T>. Acesso em: 3 abr. 2016.

FELIPE, Sônia. A desanimalização do consumo humano: desafios da ética vegana. Palestra proferida na abertura da reunião da fundação da Sociedade Vegana. 2010. Disponível em: <http://goo.gl/PBk92Q>. Acesso em: 1 mar. 2015.

FERREIRA, Afonso. Estilista faz vestido de noiva vegano e troca seda por sintéticos. 2013. Disponível em: <http://goo.gl/MLixwl>. Acesso em: 22 mar. 2015. 
FERRIGNO, Mayra Vergotti. Veganismo e libertação animal: um estudo etnográfico. 2012. Dissertação (Mestrado em Antropologia Social) - Instituto de Filosofia e Ciências Humanas, Universidade Estadual de Campinas, Campinas.

GUIMARÃES, George. Protovegetarianos. 2010. Disponível em: <http://goo. gl/OZItTo>. Acesso em: 1 mar. 2015.

INTERNATIONAL VEGETARIAN UNION. Definitions. 2013. Disponível em: <http://goo.gl/pPdpmN>. Acesso em: 17 mar. 2015.

JARED Leto posa com calça de zebra e chama atenção por corpo sarado. Quem News, 20 abr. 2014. Disponível em: <http://goo.gl/QrnDCX>. Acesso em: 23 abr. 2016.

LUBITZ, Rachel. Jenny Beavan's leather jacketdeserves a spot on every Oscar's best dressed list. 29 fev. 2016. Disponível em: <http://goo.gl/r2ssq2>. Acesso em: 5 fev. 2016.

MINISTRA da cultura sueca é alvo de críticas após cortar 'bolo racista'. G1: Globo, São Paulo, 18 abr. 2012. Disponível em: <http://goo.gl/5P8Dsx>. Acesso em: 27 abr. 2016.

MÜLLER, Bruno. Vegetarianismo, veganismo e protovegetarianismo: definições e concepções. 20 mai. 2010. Disponível em: <http://goo.gl/njqBF8>. Acesso em: 1 mar. 2015.

O ESTILO de Jared Leto. 28 dez. 2015. Disponível em: <http://goo. gl/4WFYgv>. Acesso em: 23 abr. 2016.

PETA. Catalog. Fake, not leather lapel pin. Disponível em: <http://goo.gl/ vUR1gd>. Acesso em: 6 fev. 2016.

POMPEU, Bruno. "Simulacro". In: PEREZ, Clotilde et al. (Org.). Universo sígnico da pirataria: Falso? Verdadeiro! São Paulo: Editora Imod, 2013. p. 353.

RAIO-X de estilo de Jared Leto. 2014. Disponível em: <http://goo.gl/w2bOr6>. Acesso em: 23 abr. 2016.

SABINO, Marco. Dicionário da moda. Rio de Janeiro: Elsevier, 2007. 
SALES, Alessandro Carvalho. O Problema do Simulacro: a leitura de Gilles Deleuze. In: CONGRESSO BRASILEIRO DE CIÊNCIAS DA COMUNICAÇÃO, 27., 2004, Porto Alegre. Anais ... São Paulo: Intercom, 2004. Disponível em: <http://www.portcom.intercom.org.br/pdfs/.pdf>. Acesso em: 1 mar. 2015.

SCHMIDT, Nadia. 1 mar. 2016. Quando uma jaqueta de couro fala mais alto que um Oscar. Disponível em: <http://goo.gl/rEnj5X>. Acesso em: 29 abr. 2016.

SIMULACRO. In: HOUAISS, Antonio. Dicionário Houaiss da Língua Portuguesa. São Paulo: Objetiva, 2007.

SIMULACRO. In: MICHAELIS. Dicionário prático da língua Portuguesa: nova ortografia. São Paulo: Melhoramentos, 2009.

SOCIEDADE VEGETARIANA BRASILEIRA. Vegetarianismo. 2013. Disponível em: <http://goo.gl/Wm3aOw>. Acesso em: 1 mar. 2015.

SOUZA, Robson Fernando de. 2016. Por que a intolerância a alimentos de origem animal pode atrapalhar o entendimento sobre o veganismo. $7 \mathrm{fev}$. 2016. Disponível em: <http://goo.gl/oEX6ia>. Acesso em: 27 abr. 2016.

THE INDIGESTIBLE fleshy sculpture of Cao Hui. 6 ago. 2015. Disponível em: <http://goo.gl/p4PXR8>. Acesso em: 23 abr. 2016.

THE TATA top. You made it! Welcome to the Tata Top. Disponível em: <http:// goo.gl/FwAUx7>. Acesso em: 24 abr. 2016.

VENCEDORA do Oscar de melhor figurino usa jaqueta de couro na cerimônia. Vogue Brasil, 29 fev. 2016. Disponível em: <http://goo.gl/quVdwZ>. Acesso em: 28 abr. 2016. 